\title{
PENERAPAN PROGRAM KESELAMATAN KERJA PADA FORKLIFT DI PT ALP PETRO INDUSTRY
}

\author{
APPLICATION OF SAFETY SECURITY PROGRAM FOR FORKLIFT \\ IN PT ALP PETRO INDUSTRY
}

\author{
Mochammad Angga Tri Tjahyo Adhy \\ PT. Waskita Karya \\ E-mail: mochanggatri@gmail.com
}

\begin{abstract}
Forklift is one of lift and transport aircraft that support the implementation of the production process which consist high enough of hazards, and there is a possibility of work accidents. So the prevention efforts should be made with fulfill their safety requirements, to prevent that accidents. The purpose of this study were learning the programs of health and safety of the operation forklift in PT. ALP Petro Industry Gempol, Pasuruan. This study was an observational descriptive study with cross-sectional approach. The subjects were all of the forklift operator, safety officer and supervisor, and factory general supervisor. The variables were studied were license of safety, safety tools, housekeeping, maintenance, inspection, safety sign, and wearing personal protective equipment. The primary data were obtained by using observations and interviews, and the secondary data were obtained from the company. Furthermore, the data was processed descriptively. The results showed that there are six programs have been implemented in accordance with applicable regulations, and there is one program that hasn't been accomplished in accordance with the relevant regulations that safety signs.
\end{abstract}

Keywords: safety programs, forklift

\begin{abstract}
ABSTRAK
Forklift merupakan salah satu pesawat angkat dan angkut yang mendukung pelaksanaan proses produksi dengan potensi bahaya cukup tinggi, dan terdapat kemungkinan terjadi kecelakaan kerja. Upaya pencegahannya adalah dengan cara memenuhi syarat keselamatan yang berlaku untuk mencegah terjadinya kecelakaan kerja tersebut. Tujuan dari penelitian ini adalah mempelajari penerapan program Keselamatan dan Kesehatan Kerja pada saat pengoperasian forklift di PT. ALP Petro Industry. Penelitian ini adalah penelitian deskriptif dengan pendekatan cross sectional. Subjek dari penelitian ini adalah operator forklift, safety officer dan supervisor, dan juga factory general supervisor. Variabel dari penelitian ini adalah surat ijin operator/lisensi K3, alat-alat keselamatan, tatagraha, perawatan, inspeksi, rambu keselamatan, dan penggunaan alat pelindung diri. Data primer diperoleh dengan menggunakan observasi dan wawancara, dan data sekunder diperoleh dari perusahaan. Selanjutnya data tersebut diolah secara deskriptif dan dijelaskan dalam bentuk narasi. Hasil penelitian menunjukkan bahwa terdapat enam program telah terlaksana sesuai dengan peraturan yang berlaku, dan terdapat satu program yang belum terlaksana sesuai dengan peraturan terkait yaitu rambu keselamatan.
\end{abstract}

Kata kunci: program keselamatan, forklift

\section{PENDAHULUAN}

Seiring dengan perkembangan zaman, banyak kegiatan industri pada saat ini menggunakan muatan yang sudah dikemas dalam bentuk utilisasi, hal ini diharapkan dapat mempermudah dalam melaksanakan aktivitas industri. Kegiatan tersebut membutuhkan alat angkat-angkut yang disebut dengan forklift.

Forklift merupakan salah satu jenis pesawat angkat angkutan di atas landasan dan diatas permukaan, forklift harus dilengkapi dengan sebuah atap atau pelindung lainnya yang memadai untuk mencegah terjadinya kecelakaan pada operator yang disebabkan oleh benda-benda jatuh. Konstruksi forklift pada umumnya adalah sebuah kereta roda empat yang dilengkapi dengan garpu (fork) (Rochman, 2009).

Garpu tersebut dapat naik turun, dudukan garpu dapat dimiringkan ke depan belakang karena beban terletak di depan maka roda depan tetap dan kuat, sedangkan yang berfungsi sebagai roda kemudi adalah roda belakang, pengendalian 
forklift dilakukan dari ruang kemudi, baik untuk menjalankan kendaraan maju maupun mundur untuk pengangkatan barang.

Forklift digunakan untuk membantu melakukan pekerjaan di tempat kerja seperti untuk mengangkat dan mengangkut barang yang memiliki beban berat dan banyak. Semakin banyaknya jumlah forklift yang digunakan oleh perusahaan, maka akan semakin banyak juga operator yang dibutuhkan untuk mengoperasikannya. Dalam pengoperasian forklift yang aman dan benar dibutuhkan tenaga operator yang mempunyai skill yang terlatih dan mempunyai pengetahuan tentang forklift.

Hal ini diatur di dalam PER. 09/MEN/VII/2010 Pasal 5 ayat 1 yang berbunyi:

\section{"Pesawat angkat dan angkut harus dioperasikan oleh operator pesawat angkat dan angkut yang mempunyai lisensi K3 dan buku kerja sesuai jenis dan kualifikasinya".}

Seorang pekerja PT. Hansung Fiber, jalan raya Pasarkemis-Cikupa Kabupaten Tangerang bernama SR 33 tahun, mengalami kecelakaan kerja saat mengoperasikan forklift. SR tewas terjepit antara mesin forklift dengan mesin genset. Kejadian ini terjadi pada tanggal 13 April 2013 pukul 11.20. Kejadian tersebut bermula ketika SR sedang mengoperasikan forklift, dia mengetahui bahwa solarnya sudah akan habis, maka dia membawa forklift tersebut menuju ke lokasi pengisian solar. Ketika dia berjalan membelakangi forklift tanpa disadari forklift tersebut bergerak mundur karena ketika SR turun dari mesin forklift, dia tidak mematikan mesinnya, akibatnya SR terjepit dalam posisi berdiri antara forklift dan mesin genset. SR meninggal dunia dalam perjalanan ke rumah sakit (Sudarsono, 2013).

Dari kasus kecelakaan tersebut maka sebelum mengoperasikan forklift perlu adanya syarat keselamatan kerja yang harus dipenuhi, salah satunya untuk mencegah terjadinya kecelakaan kerja dengan menerapkan metode kerja yang aman dan efisien. Menerapkan pengendalian bahaya dengan cara menyusun dan menetapkan prosedur kerja yang aman merupakan salah satu dari upaya pengendalian administratif, memberikan pelatihan kerja bagi semua operator, serta melakukan pengecekan berkala ataupun inspeksi terhadap forklift tersebut. Beberapa hal tersebut dapat membantu meminimalkan bahaya yang mungkin terabaikan dalam proses kerja.
Sehingga dengan adanya prosedur kerja yang jelas dan lebih aman, maka akan menciptakan sebuah pekerjaan menjadi lebih efektif dan efisien waktu, hal tersebut berhubungan dengan kualitas mutu, produktivitas dan mengurangi risiko kecelakaan kerja.

PT. ALP Petro Industry pada setiap proses selalu didukung alat modern salah satunya forklift. Dalam pengoperasiannya forklift memiliki potensi bahaya yang bermacam-macam, salah satunya adalah seperti peralatan pengaman pada fisik forklift yang tidak berfungsi yang dapat menimbulkan kecelakaan, operator yang mengoperasikan forklift tidak melakukan standar pengoperasian yang aman dan benar. Tidak berfungsinya lampu untuk belok, redupnya bunyi klakson. Hal-hal tersebut dapat berpotensi menimbulkan kecelakaan kerja.

Adapun tujuan penelitian ini secara umum untuk mempelajari penerapan program Keselamatan dan kesehatan Kerja (K3) pada pengoperasian forklift di PT. ALP Petro Industry Gempol, Pasuruan. Secara khusus antara lain: mempelajari penerapan alat keselamatan kerja pada forklift, melakukan inspeksi pada forklift, mempelajari surat ijin operator yang dimiliki oleh operator forklift, mempelajari rambu keselamatan yang terdapat pada PT. ALP Petro Industry, mengetahui mekanisme pelaksanaan maintenance yang dilakukan, mempelajari alat pelindung diri yang digunakan oleh operator forklift, mengetahui mekanisme pelaksanaan tatagraha yang dilakukan di perusahaan, dan mempelajari pelatihan yang telah didapatkan oleh operator forklift di PT. ALP Petro Industry.

\section{METODE}

Penelitian dilakukan di PT. ALP Petro Industry Gempol, Pasuruan. Penelitian ini dilakukan pada Juli sampai Agustus 2016. Penelitian ini dilakukan secara observasional sehingga data yang terkumpul dapat dianalisis secara deskriptif dan disajikan dalam bentuk narasi.

Metode pembelajaran yang digunakan selama penelitian berlangsung adalah observasi lapangan, hal ini dilakukan untuk mengamati dan mempelajari proses pelaksanaan implementasi Keselamatan dan Kesehatan Kerja (K3) yang berlaku pada saat pengoperasian forklift. Selain itu juga dilaksanakan pembelajaran keterampilan guna mengasah kemampuan agar dapat melaksanakan program yang berlaku pada PT. ALP Petro Industry Gempol, 
Pasuruan. Rancangan penelitian ini adalah cross sectional study dikarenakan penelitian dilaksanakan dalam kurun waktu tertentu. Data primer didapatkan dengan cara observasi. Data sekunder didapatkan dari PT. ALP Petro Industry Gempol, Pasuruan.

Sasaran dari penelitian ini adalah seorang safety supervisor. safety officer, factory general supervisor dan lima operator forklift. Data yang telah dikumpulkan kemudian diolah secara deskriptif dan disajikan dalam bentuk narasi yang akan menggambarkan dari variabel-variabel yang diteliti surat ijin operator, alat-alat keselamatan kerja, perawatan (maintenance), inspeksi, rambu keselamatan, tatagraha (housekeeping), dan juga penggunaan alat pelindung diri.

\section{HASIL}

\section{Gambaran Penerapan K3 pada Forklift di PT. ALP Petro Industry}

Sebagai industri yang bergerak di bidang pelumas industry, PT. ALP Petro Industry memerlukan alat angkat dan angkut untuk mendukung kelancaran proses produksi, salah satunya peralatan angkat dan angkutnya yaitu forklift. Forklift merupakan alat angkut yang hampir setiap hari beroperasi untuk mengangkat, mengangkut, dan memindahkan barang. Jumlah keseluruhan yang dimiliki perusahaan ini adalah 5 buah, semuanya beroperasi setiap hari.

Dasar Hukum yang digunakan oleh PT. ALP Petro Industry terkait dengan forklift antara lain Undang-Undang No. 1 Tahun 1970 Tentang Keselamatan Kerja, Permenakertrans RI No. 5/ MEN/1985 Tentang Pesawat Angkat dan Angkut, dan Permenakertrans RI No. 9/MEN/VII/2010 Tentang Operator dan Pesawat Angkat dan Angkut.

PT. ALP Petro Industry memiliki 5 buah forklift terdiri dari 2 electric dan 3 mesin diesel. Forklift nomer lambung 1 memiliki nama Patria digunakan untuk membantu pengangkutan pada proses pengemasan produk jadi (filling), lalu untuk forklift nomer lambung 2 dan 3 bernama komatsu dimana digunakan untuk membantu pengangkutan pada proses "loading finish good atau kemasan kardusan (retail), issuing addictive, dan untuk movement barang-barang maintenance. Untuk forklift nomer 4 dan 5 digunakan untuk membantu pengangkutan "loading finish good" atau produk yang dalam drum. Hal ini tidak meluput kemungkinan dilakukan bergantian apabila dalam sebuah proses membutuhkan beberapa forklift untuk pengangkutan.

\section{Surat Ijin Mengemudi Operator (SIO) Forklift}

Lisensi Keselamatan dan Kesehatan Kerja yang selanjutnya disingkat Lisensi K3 adalah kartu tanda kewenangan seorang operator untuk mengoperasikan pesawat angkat dan angkut sesuai dengan jenis dan kualifikasinya atau petugas untuk penanganan pesawat angkat dan angkut.

Operator adalah tenaga kerja yang mempunyai kemampuan dan memiliki keterampilan khusus dalam pengoperasian pesawat angkat dan angkut. Di PT. ALP Petro Industry semua operator telah mendapatkan SIO.

Buku kerja (logbook) adalah buku kerja yang diberikan kepada seorang operator untuk mencatat kegiatan selama mengoperasikan pesawat angkat dan angkut sesuai dengan jenis dan kualifikasinya atau petugas untuk mencatat penanganan pesawat angkat dan angkut.

Berdasarkan hasil observasi dan wawancara yang dilakukan oleh peneliti terhadap factory general supervisor didapatkan data bahwa PT. ALP Petro Industry memiliki 11 (sebelas) operator forklift, dengan rincian 5 untuk operator utama dan 6 untuk operator cadangan. Hasil wawancara terhadap seluruh operator forklift di PT. ALP Petro Industry, maka didapatkan bahwa seluruh operator yang mengoperasikan forklift tersebut telah memiliki lisensi atau SIO kelas II seluruhnya.

\section{Alat-Alat Safety pada Forklift}

PT. ALP Petro Industry memiliki alat-alat keselamatan yang disediakan untuk mendukung keselamatan forklift. Baik itu keselamatan operator, keselamatan barang yang diangkat dan diangkut, maupun keselamatan orang yang berada di sekeliling forklift. Alat tersebut antara lain, alat pelindung diri, rotary lamp, alarm mundur, klakson, kaca spion, dan yang terakhir catokan/garpu kuning.

Alat pelindung diri, alat keamanan ini sangat diperlukan untuk keselamatan operator. APD yang tersedia pada forklift adalah masker, rompi, serta helm. Masker digunakan untuk melindungi pernapasan operator dari debu-debu yang beterbangan dari barang yang diangkut maupun dari forklift itu sendiri. Sedangkan helm berfungsi untuk melindungi kepala operator dari barang jatuh. Selain itu juga terdapat alat pelindung diri khusus 
yaitu raincoat yang digunakan hanya ketika terjadi hujan saat pengoperasian.

Rotary lamp, lampu ini diperlukan saat forklift beroperasi, yaitu sebagai tanda bahwa terdapat forklift yang sedang beroperasi sehingga diharapkan dapat meminimalisir terjadinya kecelakaan kerja tertabrak forklift. Namun pada kenyataannya masih terdapat beberapa rotary lamp pada forklift yang sudah tampak redup.

Alarm mundur, alarm ini berguna untuk keselamatan orang yang berada di sekeliling forklift. Jarak pandang operator forklift yang berjalan mundur cenderung berkurang sehingga dengan adanya alarm tersebut setiap orang yang berada di sekitar forklift bisa menjauh setelah mendengar alarm tersebut.

Klakson, hal ini berfungsi untuk peringatan terhadap orang yang berada di sekitar forklift agar tidak mendekati forklift sehingga kecelakaan kerja berupa tertabrak forklift bisa dikurangi. Namun dari hasil inspeksi pada bulan Agustus terdapat 1 forklift yang nyala klaksonnya sudah mulai pelan.

Kaca spion, peralatan ini digunakan ntuk operator yang berjalan mundur akibat beban yang melebihi batas ketinggian dapat menggunakan spion untuk melihat belakang forklift agar tidak menabrak. Pada forklift di PT. ALP Petro Industry sudah terpasang kaca spion dengan baik.

Catokan/garpu kuning, kegunaan alat ini ialah untuk operator yang akan melakukan pengangkutan drum yang mengangkut dalam jumlah yang banyak, namun adakalanya operator hanya melakukan penjepitan pada drum atau tidak perlu menggunakan catokan, semua hal ini dipertimbangkan dengan kondisi yang terjadi di lapangan.

\section{Perawatan (Maintenance) Forklift}

Menurut buku informasi alat berat dari UPI, perawatan itu dapat didefinisikan sebagai usahausaha atau tindakan-tindakan termasuk pencegahan dan perbaikan yang dilakukan untuk menjaga agar kondisi dan performance sebuah alat berat selalu seperti kondisi dan performance ketika masih baru atau semula.

Perawatan bagian forklift yang dilakukan oleh PT. ALP Petro Industry adalah periodical maintenance, yaitu setiap pencapaian jarak tempuh 125, 250, 500, 1000, dan $2000 \mathrm{~km}$. Selain masa tersebut, bagian forklift di service hanya jika terjadi kerusakan atau keluhan dari operator saat pemakaian. Setiap hari pun semua forklift di checklist oleh operator pada saat sebelum beroperasi. Maintenance atau perawatan forklift di PT. ALP Petro Industry dibagi menjadi 2.

Pertama, dilakukan setiap pagi oleh workshop dan operator forklift. Dengan jadwal sesuai nomor urut lambung, hari Senin untuk nomor 1, Selasa untuk nomor 2, Rabu untuk nomor 3, dan begitu seterusnya. Pengecekan rutin tiap pagi meliputi:

Pengecekan oli, yang dimaksud dalam hal ini baik itu oli hidrolis yang digunakan untuk penggerak lift maupun oli mesin yang digunakan untuk melumasi mesin. Oli tersebut diganti setiap 1000 jam yang dicek dengan menggunakan barometer pengecek oli.

Pengisian air radiator pada forklift diesel. Air yang digunakan untuk mengisi radiator tersebut adalah air keran biasa yang diambil dari sumber air terdekat. Dan pengecekan baterai untuk forklift electric.

Cek filter udara berfungsi untuk menyaring debu agar tidak masuk ke dalam motor. Cara membersihkannya dilakukan dengan menyemprotkan udara dengan menggunakan kompresor seminggu sekali.

Pengisian aki dilakukan jika air aki menunjukkan batas lower level. Jika air aki masih pada batas upper level maka aki tidak perlu ditambahkan.

Pengecekan roda, hal ini terkait dengan ketebalan roda dimana tidak boleh melebihi batas safety. Selain itu juga perlu diberikan grease pada roda agar forklift dapat berjalan dengan halus dan nyaman.

Pengecekan rantai meliputi tekanan 2 buah rantai harus sama saat mengangkat barang. Selain itu rantai pada forklift juga harus diberi oli agar tidak terjadi aus.

Pengecekan hidrolis, van belt dan yang terakhir ialah pengecekan buzzer meliputi: lampu rotary, lampu sein, klakson, dan lain-lain.

Setiap 3 bulan sekali, seluruh forklift wajib dilaksanakan maintenance. Hal ini berbeda dengan daily maintenance yang dilakukannya secara bergantian, jika saat jadwal maintenance 3 bulan sekali maka seluruh forklift harus dilakukan maintenance serentak tanpa terkecuali.

\section{Inspeksi Forklift}

Inspeksi adalah upaya deteksi dini dan mengoreksi adanya potensi bahaya di tempat kerja yang dapat menimbulkan kecelakaan. Inspeksi tempat kerja bertujuan untuk mengidentifikasi 
sumber-sumber bahaya potensial yang ada di tempat kerja, mengevaluasi tingkat risiko terhadap tenaga kerja serta mengendalikan sampai tingkat yang aman bagi Keselamatan dan Kesehatan Kerja (K3). Inspeksi tidak ditujukan untuk mencari kesalahan orang, melainkan untuk menemukan dan menentukan lokasi bahaya potensial yang dapat mengakibatkan kecelakaan dan penyakit akibat kerja (Sahab, 1997).

Menurut Bird dan Germain (1986) bahwa inspeksi merupakan suatu cara terbaik untuk menemukan masalah-masalah dan menilai risikonya sebelum kerugian atau kecelakaan dan penyakit akibat kerja benar-benar terjadi.

Berdasarkan hasil wawancara kepada factory general supervisor, didapatkan hasil bahwa frekuensi inspeksi menurut dasar hukum yang berlaku dan mengatur hal tersebut seharusnya perawatan dilakukan setiap 6 (enam) bulan sekali. Pihak logistic selaku pihak yang menangani terkait segala sesuatu yang berhubungan dengan forklift menginginkan pelaksanaannya dilakukan setiap 4 bulan sekali. Hal ini sangat berguna untuk meminimalisir angka kejadian near miss pada forklift.

\section{Pelatihan Tenaga Kerja/Training}

Menurut Schermerhorn (1999), pelatihan merupakan serangkaian aktivitas atau kegiatan yang memberikan kesempatan kepada karyawan/ pekerja untuk mendapatkan dan meningkatkan keterampilan yang dimiliki sehingga keterampilan tersebut berkaitan dengan pekerjaannya.

Tujuan umum dari pelatihan adalah untuk dapat mengembangkan keahlian, memperluas pengetahuan, dan mengembangkan sikap guna mempermudah pekerja atau karyawan untuk dapat menyelesaikan pekerjaannya dengan lebih cepat dan efektif, juga dapat melakukan pekerjaannya dengan rasional, dan juga dapat menimbulkan atau menumbuhkan rasa kerja sama dengan teman-teman pegawai ataupun pimpinan (Moekijat, 1991).

Tujuan tersebut dapat tercapai dengan mudah apabila pimpinan menyadari akan pentingnya pelatihan yang sistematis. Selain itu juga pekerja tersebut harus percaya bahwa mereka akan memperoleh keuntungan dari mengikuti pelatihan tersebut.

Pelatihan merupakan salah satu usaha dalam meningkatkan mutu sumber daya manusia dalam organisasi, pekerja baru ataupun yang sudah lama perlu mengikuti pelatihan karena adanya tuntutan pekerjaan yang dapat berubah akibat perubahan lingkungan kerja, strategi, dan lain sebagainya.

PT. ALP Petro Industry telah memberikan pelatihan tenaga kerja/training kepada operator forklift diantaranya general, $\mathrm{K} 3 \mathrm{~L}$, dan technical. Adapun tema pelatihan tersebut antara lain mengani kecakapan mengenai cara pengoperasian, ergonomic pada operator forklift, dan cara memperlakukan forklift.

\section{Rambu Keselamatan (Safety Sign)}

Safety sign atau rambu keselamatan merupakan media visual berupa gambar atau tulisan yang ditempatkan di area kerja yang memuat pesan agar setiap tenaga kerja memperhatikan aspek-aspek Keselamatan dan Kesehatan Kerja (K3).

Di PT. ALP Petro Industry terdapat beberapa safety sign atau rambu keselamatan untuk forklift, diantaranya terdapat palang khusus untuk menandakan bahwa jalur tersebut hanya boleh dilewati oleh forklift ketika terdapat forklift yang beroperasi, kemudian terdapatnya jalur khusus untuk forklift di area gudang penyimpanan, dipasangnya kaca cembung guna meminimalisir terjadinya tabrakan antar forklift di setiap tikungan.

\section{Tatagraha (Housekeeping)}

Tatagraha (housekeeping) merupakan kegiatan yang dilakukan untuk membuat suatu daerah/fasilitas menjadi bersih dan teratur. Berdasarkan hasil observasi, seluruh area di PT. ALP Petro Industy telah melakukan housekeeping mulai dari plant, gudang penyimpanan, factory general, waste water treatment, hingga seluruh office baik front office maupun yang berada di dalam plant.

PT. ALP Petro Industry sendiri membagi kegiatan housekeeping menjadi 2 macam, yaitu internal dan external. Housekeeping internal dilakukan pada pagi hari pukul 08.00 pagi sampai dengan 08.30 pagi. Untuk yang external dilakukan secara nonstop dengan cara keliling plant setiap saat.

Housekeeping yang dilakukan antara lain: membersihkan seluruh material sisa yang berada di seluruh area, menata kembali seluruh material sesuai dengan letaknya, membersihkan tumpahan oli ataupun minyak dengan cara menaburkan serbuk gergaji di area tersebut, dan lain-lain. 


\section{Penyediaan Alat Pelindung Diri (APD)}

Alat pelindung diri (APD) adalah suatu alat perlengkapan tenaga kerja untuk melindungi anggota badan dari bahaya yang ditimbulkan oleh keadaan kerja sebagai akibat dari pengaruh pesawat, alat, mesin dan bahan-bahan. Alat pelindung diri (APD) dapat berfungsi semaksimal mungkin sesuai dengan spesifikasi bahaya yang ada.

APD yang digunakan oleh operator forklift di PT. ALP Petro Industri antara lain adalah: safety helmet, masker, rompi dan safety shoes. Terdapat APD lain yang digunakan saat kondisi-kondisi tertentu, seperti rain coat dan cotton gloves.

\section{PEMBAHASAN}

\section{Surat Ijin Mengemudi Operator (SIO) Forklift}

Surat Ijin Operator atau lisensi kesehatan dan keselamatan kerja (K3) merupakan sejenis sertifikat yang diberikan menyangkut surat ijin perorangan didalam sebuah perusahaan dalam hal kelayakan pengoperasian alat angkat angkut. Keharusan memiliki lisensi atau SIO diatur di dalam Peraturan Menteri Tenaga Kerja dan Transmigrasi nomor PER.09/MEN/VII/2010 Pasal 5 ayat 1 yang berbunyi:

\section{"Pesawat angkat dan angkut harus dioperasikan oleh operator pesawat angkat dan angkut yang mempunyai lisensi K3 dan buku kerja sesuai jenis dan kualifikasinya."}

Dari hasil observasi dan wawancara dari berbagai pihak antara lain factory general supervisor dan juga seluruh operator forklift didapatkan bahwa seluruh operator telah memiliki Surat Ijin Operator (SIO) kelas 2, seluruh operator yang memiliki SIO kelas 2 sebagaimana yang dimaksud dalam Pasal 12 huruf $\mathrm{b}$ telah memenuhi persyaratan antara lain sekurang-kurangnya berpendidikan SLTP/sederajat; berpengalaman sekurang-kurangnya 1 (satu) tahun membantu pelayanan di bidangnya; berbadan sehat menurut keterangan dokter, umur sekurangkurangnya 19 tahun; dan juga telah memiliki Lisensi Keselamatan dan Kesehatan Kerja (K3) dan buku kerja.

Selain itu hal ini juga sesuai dengan Peraturan Menteri Tenaga Kerja dan Transmigrasi Nomor PER.09/MEN/ VII/2010 Pasal 4 yang berbunyi:
"Jumlah operator pesawat angkat dan angkut yang dipekerjakan oleh pengusaha atau pengurus harus memenuhi kualifikasi dan jumlah sesuai dengan jenis dan kapasitas pesawat angkat dan angkut sebagaimana tercantum dalam Lampiran Peraturan Menteri ini."

Berdasarkan hasil tersebut, maka dapat dikatakan bahwa PT. ALP Petro Industry telah mematuhi peraturan yang berlaku dimana setiap operator pesawat angkat dan angkut, dimana seluruh operator harus memiliki lisensi Kesehatan dan Keselamatan Kerja (K3) dan buku kerja sesuai jenis dan kualifikasinya yang masih berlaku sesuai dengan peraturan.

\section{Alat-Alat Safety pada Forklift}

Alat keselamatan yang terletak pada forklift diharapkan dapat mendukung keselamatan, keselamatan barang yang diangkat dan diangkut, maupun keselamatan orang yang berada di sekeliling forklift tersebut.

Sesuai dengan hasil observasi yang dilakukan selama penelitian berlangsung didapatkan bahwa telah terdapat banyak macam alat keselamatan pada forklift tersebut. Terpasangnya/terdapatnya alat-alat keselamatan pada forklift di PT ALP Petro Industry berhubungan dengan kepedulian perusahaan ini yang sangat tinggi terkait dengan keselamatan saat pengoperasian forklift.

Berdasarkan hasil yang didapatkan, maka salah satu program keselamatan pada saat pengoperasian forklift dapat dikatakan telah terlaksana dengan sangat baik. Diharapkan kecelakaan kerja terkait operator, barang yang diangkat dan diangkut maupun orang yang berada di sekeliling forklift tersebut dapat dicegah.

\section{Maintenance Forklift}

Menurut buku informasi alat berat dari UPI, perawatan itu dapat didefinisikan sebagai usahausaha atau tindakan-tindakan termasuk pencegahan dan perbaikan yang dilakukan untuk menjaga agar kondisi dan performance sebuah alat berat selalu seperti kondisi dan performance ketika masih baru atau semula.

Berdasarkan Peraturan Menteri Tenaga Kerja No. PER.05/MEN/1985 tentang pesawat angkat dan angkut pasal 138 ayat 4 yang berbunyi: 


\begin{abstract}
"Pemeriksaan dan pengujian ulang pesawat angkat dan angkut dilaksanakan selambat-lambatnya 2 (dua) tahun setelah pengujian pertama dan pemeriksaan pengujian ulang selanjutnya dilaksanakan 1 (satu) tahun sekali."
\end{abstract}

Sebagaimana telah dijelaskan pada peraturan tersebut bahwasanya pemeriksaan dan pengujian ulang pesawat angkat dan angkut seharusnya dilakukan 2 (dua) tahun setelah pengujian pertama dan rutin dilakukan pemeriksaan dan pengujian tiap 1 (satu) tahun sekali.

Maka sesuai hasil wawancara yang dilakukan, PT. ALP Petro Industry telah mematuhi peraturan yang berlaku dengan cara melakukan perawatan (maintenance) telah dilaksanakan dengan rutin. PT. ALP Petro Industry melaksanakan maintenance setiap hari dan juga setiap 3 bulan sekali.

\section{Inspeksi Forklift}

Inspeksi merupakan sebuah upaya untuk mencegah terjadinya kecelakaan kerja ataupun penyakit akibat kerja. Inspeksi ini bertujuan untuk mengidentifikasi sumber bahaya potensial apa saja yang dapat terjadi di tempat kerja, selain itu juga untuk mengevaluasi tingkat risiko dan juga untuk dapat mengendalikan sampai menuju tingkat risiko yang aman bagi tenaga kerja.

Sesuai dengan hasil wawancara yang dilakukan, bahwasanya didapatkan inspeksi yang dilakukan oleh PT. ALP Petro Industry telah sesuai dengan Peraturan Menteri Tenaga Kerja dan Transmigrasi nomor PER. 09/MEN/VII/2010 Pasal 34 ayat 1a yang berbunyi:

\footnotetext{
"Operator pesawat angkat dan angkut berkewajiban untuk: a. melakukan pengecekan terhadap kondisi atau kemampuan kerja pesawat angkat dan angkut, alat-alat pengaman, dan alatalat perlengkapan lainnya sebelum pengoperasian pesawat angkat dan angkut."
}

PT. ALP Petro Industry memiliki kebijakan sendiri yang lebih baik, seharusnya dilakukan 6 bulan sekali. Namun PT. ALP Petro Industry ingin melaksanakan 4 bulan sekali. Hal ini diharapkan dapat meminimalisir angka near miss yang terjadi saat pengoperasian forklift. Maka program inspeksi milik PT. ALP Petro Industry telah terlaksana dengan sangat baik.

\section{Pelatihan Tenaga Kerja/Training}

PT. ALP Petro Industry telah melaksanakan program pemberian pelatihan bagi tenaga kerja dengan sangat baik, sebagaimana telah dijelaskan pada hasil, terdapat 3 (tiga) penelitian yang telah didapat oleh operator forklift di PT. ALP Petro Industry. Program pelatihan yang telah terlaksana ini sesuai dengan yang tertulis di dalam UndangUndang No. 13 Tahun 2003 Pasal 11 tentang Pelatihan Kerja, yang berbunyi:

\section{"Setiap tenaga kerja berhak untuk memperoleh dan atau mengembangkan kompetensi kerja sesuai dengan bakat, minat, dan kemampuannya melalui pelatihan kerja."}

Pelatihan tersebut diharapkan dapat bermanfaat guna meningkatkan kompetensi, minat, dan kemampuan operator forklift dalam pengoperasian forklift di PT. ALP Petro Industry. Pelatihan yang telah didapat oleh operator sebaiknya dilakukan review ulang sehingga seluruh informasi yang didapat selama pelatihan berlangsung dapat terasah kembali.

\section{Rambu Keselamatan/Safety Sign}

Rambu atau simbol keselamatan dan kesehatan kerja (K3) adalah peralatan yang bermanfaat untuk membantu melindungi kesehatan dan keselamatan para karyawan dan pengunjung yang sedang berada di tempat kerja.

Rambu keselamatan berguna untuk menarik perhatian terhadap adanya bahaya Keselamatan dan Kesehatan Kerja (K3), menunjukkan adanya potensi bahaya yang mungkin tidak terlihat, menyediakan informasi umum dan memberikan pengarahan, dan memberi peringatan pada para karyawan bahwa mereka harus menggunakan peralatan pelindung diri.

Selain itu juga dapat mengindikasikan letak peralatan darurat keselamatan berada dan juga memberikan peringatan waspada terhadap beberapa tindakan atau perilaku yang tidak diperbolehkan (Abdurrahman, 2013).

Contoh rambu-rambu peringatan antara lain peringatan bahaya dari atas, peringatan bahaya benturan kepala, peringatan untuk memakai alat pelindung diri, petunjuk ketinggian penumpukan material, larangan memasuki area tertentu, dan lain-lain. 
Berdasarkan Undang-undang No. 1 Tahun 1970 Pasal 14b yang berbunyi:

"Memasang dalam tempat kerja yang dipimpinnya, sетua gambar keselamatan kerja yang diwajibkan dan semua bahan pembinaan lainnya, pada tempat-tempat yang mudah dilihat dan terbaca menurut petunjuk pegawai pengawas atau ahli keselamatan kerja."

Dari peraturan di atas dapat diketahui bahwa PT. ALP Petro Industry belum mengimplementasikan peraturan tersebut dengan sesuai karena tampak beberapa jalur forklift warna catnya sudah memudar, hal ini menyebabkan tidak tampaknya pemisah antara jalur pejalan kaki, jalur penumpukan drum dan juga jalur forklift. Hal ini tidak sesuai dengan peraturan, rambu-rambu harus mudah terlihat dan terbaca. Maka baiknya dilakukan pengecatan ulang di beberapa lokasi jalur yang warna catnya sudah mulai memudar. Selain itu juga terdapat beberapa cermin cembung yang terlihat kotor sehingga pantulan cermin tersebut tidak cukup baik seharusnya lebih diperhatikan dalam perawatan rambu-rambu yang berada di PT. ALP Petro Industry.

Secara keseluruhan PT. ALP Petro Industry telah memasang rambu-rambu keselamatan, namun banyak rambu-rambu tersebut mulai tidak dapat berfungsi maksimal salah satunya yaitu sulit terlihat dan terbaca, maka sebaiknya dilakukan perawatan terhadap rambu-rambu tersebut.

Selain itu juga dapat dilakukan penambahan beberapa rambu, antara lain rambu hati-hati, serta rambu batas kecepatan guna mencegahnya forklift berjalan melebihi standar keselamatan yang telah ditentukan oleh PT. ALP Petro Industry, selain itu juga hal ini dapat mencegah terjadinya kecelakaan kerja yang hampir setiap pengangkutan yang dilakukan oleh forklift dilakukan dengan cara berjalan mundur.

\section{Tatagraha (Housekeeping)}

Berdasarkan hasil data yang didapat dengan dilakukannya observasi, program housekeeping baik internal maupun eksternal di PT. ALP Petro Industry sudah terlaksana dengan baik, dan sesuai dengan Undang-Undang No. 1 Tahun 1970 tentang Keselamatan Kerja pasal 3 ayat 1 point (L) yang menyebutkan (Depnaker RI, 1999).

"Salah satu syarat terciptanya keselamatan kerja adalah memelihara kebersihan, kesehatan dan ketertiban di tempat kerja."

Dengan adanya tatagraha ini dapat menciptakan lingkungan kerja di PT. ALP Petro Industry menjadi bersih dan nyaman untuk pekerja lainnya, sehingga diharapkan dapat meningkatkan produktivitas tenaga kerja.

\section{Penyediaan Alat Pelindung Diri}

Menurut Habsari (2003), alat pelindung diri adalah seperangkat alat yang digunakan karyawan atau tenaga kerja untuk melindungi sebagian atau seluruh tubuhnya dari adanya potensi bahaya kecelakaan kerja.

Alat pelindung diri (APD) adalah Alat yang digunakan seorang dalam melakukan pekerjaan dengan maksud melindungi diri nya dari sumber bahaya tertentu, baik yang berasal dari pekerjaan dan lingkungan kerja, dan berguna dalam usaha atau mencegah atau mengurangi kemungkinan cedera atau sakit (Syukri, 1997).

Sesuai dengan hasil observasi yang dilakukan, seluruh operator forklift telah menggunakan alat pelindung diri yang disediakan oleh PT ALP. Petro Industry. Hal ini berkaitan dengan program K3 terkait penggunaan alat pelindung diri telah sesuai dengan Undang-undang No 1 Tahun 1970 pasal 12 butir B: Dengan peraturan perundangan diatur kewajiban atau hak tenaga kerja untuk memakai alat pelindung diri (APD). Pasal 14 butir C: Pengurus diwajibkan menyediakan alat pelindung diri (APD) secara cuma-cuma.

\section{SIMPULAN}

Seluruh forklift telah memiliki alat keselamatan yang baik, diantaranya: lampu rotary, alarm untuk mundur, alat pelindung diri yang disediakan untuk operator, dan klakson. Kemudian kaca spion yang selalu digunakan karena hampir seluruh pengangkutan di PT ALP Petro Industry dilakukan dengan berjalan mundur. Terakhir terdapat catokan/ garpu kuning yang berfungsi untuk mempermudah dalam pengangkutan drum guna meminimalisir terjadinya near miss saat pengangkutan. Namun untuk alat keselamatan garpu kuning belum digunakan secara optimal, karena jika pengangkutan drum digunakan menggunakan garpu kuning, maka akan berdampak pada jumlah drum yang akan diangkut tidak akan sebanyak jika dibandingkan pada saat tidak menggunakan alat tersebut. Hal ini 
sangat berkaitan dengan target jumlah pengangkutan drum yang telah ditentukan oleh perusahaan.

Hasil inspeksi menunjukkan bahwa terdapat beberapa hal yang harus dilakukan perbaikan, antara lain: suara klakson yang sudah mulai berkurang intensitasnya, kondisi ban yang sudah tampak halus, lampu rotary yang sudah redup, dan terdapat beberapa forklift yang warna catnya sudah mulai memudar. Selain itu juga hilangnya tutup baterai pada 2 (dua) forklift electric, hour meter tidak berfungsi, dan juga beberapa forklift tampak kotor.

Seluruh operator terdiri dari lima operator forklift utama dan enam operator cadangan. Seluruh operator telah memiliki Surat Ijin Operator (SIO) dan buku kerja yang masih berlaku. Operator forklift utama memiliki Surat Ijin Operator (SIO) kelas satu, sedangkan untuk operator forklift cadangan telah memiliki Surat Ijin Operator (SIO) kelas dua. PT. ALP Petro Industry memiliki lima forklift terdiri dari tiga mesin diesel dan dua electric. Forklift tersebut dioperasikan oleh lima operator forklift utama pada setiap harinya.

Rambu keselamatan yang terdapat di PT. ALP Petro Industry sudah mulai susah terlihat dan terbaca, hal ini dikarenakan beberapa rambu sudah tampak kotor dan hilang warnanya. Terdapat beberapa jalur forklift warna catnya sudah tampak memudar dan susah dilihat di area penyimpanan drum. Selain itu juga terdapat beberapa cermin cembung di setiap tikungan yang sudah kotor. Hal ini membuat operator forklift kesusahan untuk melihat kondisi tikungan saat akan berbelok. Belum terdapatnya rambu hati-hati dan juga rambu batas kecepatan.

Maintenance yang dilakukan oleh PT. ALP Petro Industry telah terlaksana dengan sangat baik karena perusahaan tersebut memiliki standar maintenance sendiri. Maintenance dilakukan terjadwal pada tiap hari yang dilaksanakan oleh divisi workshop. Selain itu juga terdapat pemeriksaan rutin tiap pagi yang dilaksanakan oleh operator forklift, dan juga terdapat pemeriksaan setiap 3 bulan sekali yang dilakukan pada seluruh forklift oleh divisi workshop bersama operator forklift.

PT. ALP Petro Industry menyediakan beberapa Alat Pelindung Diri (APD) yang harus dikenakan oleh operator forklift antara lain APD wajib dan juga APD khusus. Alat Pelindung Diri (APD) wajib yaitu: safety shoes, safety helmet, masker, dan juga rompi. Alat Pelindung Diri (APD) khusus antara lain rain coat dan cotton gloves, APD ini digunakan hanya pada kondisi-kondisi tertentu misalnya pada saat hujan atau pada saat akan melakukan pengisian oli.

Seluruh operator forklift di PT. ALP Petro Industry telah mendapatkan pelatihan dengan 3 macam, yaitu: general, Kesehatan dan Keselamatan Kerja Lingkungan (K3L), dan juga teknis. Hal ini berguna untuk operator forklift guna mengembangkan kompetensi kerja sesuai dengan bakat, minat, dan kemampuannya melalui pelatihan kerja, dan juga berguna untuk meminimalisir terjadinya kecelakaan kerja dengan cara meningkatkan pengetahuan yang dimiliki oleh operator forklift PT. ALP Petro Industry.

Tatagraha (housekeeping) di PT. ALP Petro Industry terlaksana dengan sangat baik dan terjadwal baik internal maupun external. Petugas tatagraha bagian external juga melaksanakannya dengan cukup sigap, antara lain menata kembali beberapa material yang tidak tertata dengan baik, membersihkan seluruh material sisa di seluruh plant yang dapat menyebabkan near miss dan juga membersihkan tumpahan oli ataupun minyak dengan serbuk gergaji yang berada di area penyimpanan drum terutama pada jalur forklift.

\section{DAFTAR PUSTAKA}

Abdurrahman, S. 2013. Modul Kesehatan dan Keselamatan Kerja. Pp. 26.

Bird E.F. Jr., dan Germain L.G. 1986. Practical Loss Control Leadership. Published by Institute Publishing, Division of International Loss Control Institute. Georgia, USA.

Depnaker. RI. 1999. Modul Pelatihan Sertifikasi Operator Forklift. Jakarta: Departemen Tenaga Kerja dan Transmigrasi.

Habsari, N.D. 2003. Penggunaan Alat Pelindung Diri Bagi Tenaga Kerja. Bunga Rampai Hiperkes dan Keselamatan Kerja. Semarang: Universitas Diponegoro.

Moekijat. 1991. Latihan dan Pengembangan Layanan Pegawai. Bandung: Mandar Maju.

Permenakertrans RI. No. 5/MEN/1985 tentang Pesawat Angkat dan Angkut. Jakarta: Kementerian Tenaga Kerja dan Transmigrasi.

Permenakertrans RI. No. 9/MEN/VII/2010 tentang Operator dan Pesawat Angkat dan Angkut. Jakarta: Kementerian Tenaga Kerja dan Transmigrasi.

Rochman, R. 2009. Penerapan Syarat-Syarat Keselamatan Kerja Forklift sebagai Upaya 
Pencegahan Kecelakaan Kerja pada Unit Produksi PT. Surya Rengcontainers. Tugas Akhir. Surabaya: Universitas Airlangga.

Schermerhorn, Jr., John R. 1999. Manajemen, diterjemahkan oleh M. Purnama Putranta dan Surya Dharma, Edisi Pertama. Yogyakarta.

Sudarsono, R.P. 2013. Pekerja Tewas Terjepit Forklift. http://kompas.com (sitasi 20 Agustus 2016).
Syukri, Sahab. 1997. Teknik Manajemen Keselamatan dan Kesehatan Kerja. Jakarta: Bima Sumber Daya Manusia.

Undang-Undang No. 1 Tahun 1970 tentang Keselamatan Kerja. Jakarta: Kementerian Tenaga Kerja dan Transmigrasi.

Undang-Undang No. 13 Tahun 2003 Pasal 11 tentang Ketenagakerjaan. Jakarta: Kementerian Tenaga Kerja dan Transmigrasi. 